ISSN 2179-6750

\title{
Educação Nutricional na Aprendizagem Significativa no "Projeto Horta" do Programa Promoção da Saúde e Segurança Alimentar e Nutricional da Universidade Federal de Viçosa
}

\author{
Mariana de Souza Faria, Mariana Candido, Glauce Dias da Costa, Graziele Santos Conceição \\ Gonsalves, Daniela Souza Lima, Lívia Carvalho Sette
}

\section{Resumo}

O Projeto Horta é uma iniciativa do PROSSAN- Programa Promoção da Saúde e de Segurança Alimentar e Nutricional, da Universidade Federal de Viçosa, iniciado no primeiro semestre de 2016 na instituição APOV- Associação Assistencial e Promocional da Pastoral da Oração de Viçosa. A APOV é uma entidade sem fins lucrativos que tem como missão promover ações educacionais, capacitando as crianças, jovens e suas famílias a desenvolverem seus valores e habilidades. $\mathrm{O}$ Projeto teve como objetivo principal a inserção da educação nutricional no processo de crescimento e aprendizagem das crianças da entidade a partir da relação ser humano-natureza, pertencimento e respeito para a educação nutricional, desenvolvendo atividades a fim de gerar a compreensão, autonomia e aquisição de hábitos saudáveis. Foi realizado um total de 10 oficinas. A primeira visouse a compreensão do que é a natureza e sua relação com o ser humano, onde foram trabalhados recortes e colagens de revistas obtidas pelos próprios alunos de acordo com o seu entendimento sobre o tema. Durante a segunda oficina houve uma explicação acerca da composição estrutural de uma planta e a importância de cada uma para o seu crescimento. Como atividade os alunos realizaram a montagem da estrutura de uma planta com peças de papel. Na terceira foi realizada uma visita à chácara da $\mathrm{APOV}$, visando a compreensão dos diversos tipos de plantio. Da quarta à oitava oficina foram realizadas atividades de plantio e manejo e apresentados os tipos de culturas, onde os alunos foram aprendendo com o direcionamento das monitoras na prática. Na nona foram discutidos manejo e suas implicações no crescimento da planta. Para finalizar, na décima oficina, foi realizada uma nova visita a chácara para a colheita de algumas hortaliças plantadas pelos próprios alunos. Logo após houve a preparação dessas hortaliças e a revisão dos conteúdos das oficinas anteriores, relembrando tópicos de higienização corporal, do ambiente e do alimento. $\mathrm{O}$ encerramento do ciclo se deu com um piquenique e adubagem da horta com os restos orgânicos da preparação. Durante o decorrer das oficinas pode-se observar o envolvimento dos alunos e a compreensão dos conteúdos ao longo das atividades, foi possível notar uma maior aceitação das hortaliças nos pratos das crianças durante o almoço, pois elas se sentiam responsáveis pelo alimento que elas mesmas haviam plantado. Além disso, houve relatos das crianças, como a seguinte fala: "Quero ser agricultor um dia". Diante de todos os resultados obtidos com as atividades é possível concluir que é essencial no processo de identificação com o alimento o desenvolvimento, entendimento e respeito pela agricultura, além do processo de transformação do conhecimento e aquisição da autonomia das crianças acerca de plantio, colheita e preparação dos alimentos para uma educação nutricional.

Descritores: Educação Nutricional; Autonomia; Aprendizagem significativa. 